\title{
イオン交換分離ー原子スペクトル分析法による 鉄鋼中微量金属の定量
}

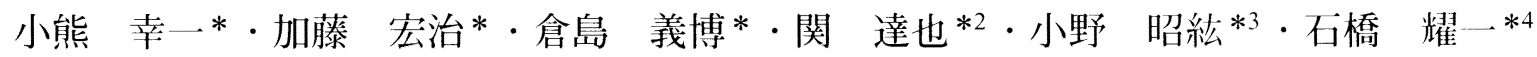

Determination of Traces of Metals in Steel by Ion-exchange Separation and Atomic Spectrometry

Koichi Oguma, Kouji Kato, Yoshihiro Kurashima, Tatsuya SeKI, Akihiro Ono and Yoichi Ishibashi

Synopsis : Novel two methods for determination of trace metals in steel have been developed by combining ion-exchange separation and atomic spectrometry. Sample is decomposed with hydrochloric acid and hydrogen peroxide. For the determination of Mo of $0.01 \mathrm{~m} / \mathrm{m} \%$ level, the sample is loaded as dilute sulfuric acid solution on a column of anion-exchanger TEVA resin. Iron ion passes through the column and Mo ion retained on the column is then recovered by elution with nitric acid, followed by quantification by inductively coupled plasma atomic emission spectrometry (ICP-AES). For the simultaneous determination of Al, Mn, Ni and Co of 0.001 to $0.1 \mathrm{~m} / \mathrm{m} \%$ level, the sample is loaded as hydrochloric acid-oxalic acid-hydrogen peroxide solution on a cation-exchange resin Bio-Rad AG 50W column. Iron ion passes the column as oxalato-complexes, and $\mathrm{Al}, \mathrm{Mn}, \mathrm{Ni}$ and $\mathrm{Co}$ ions retained on the column are eluted with hydrochloric acid to be subjected to the simultaneous determination by ICP-AES (for metals of 0.01 to $0.1 \mathrm{~m} / \mathrm{m} \%$ level) or "one drop" flame atomic absorption spectrometry (for metals of $0.001 \mathrm{~m} / \mathrm{m} \%$ level). The analytical results obtained for the steel certified reference materials are in good agreement with certified values and the precision (R.S.D. $=1$ to $8 \%$ ) is satisfactory.

Key words: ion-exchange separation; inductively coupled plasma atomic emission spectrometry; atomic absorption spectrometry; quantitative analysis; steel; Mo; Al; Mn; Ni; Co.

\section{1. 緒言}

近年，従来の純鉄と特性が異なる高純度の電解鉄が生産 されるようになり ${ }^{1.21}$ ，これを用いた鉄-50クロム合金など の新特性の合金が作られている2)。このような高純度鉄の 研究開発には, 微量不純物元素の正確な測定が要求される さらに，スクラップ利用製鍊技術の確立の上でも鋼中不純 物元素の管理が重要課題になってきている。

一方，最近の分析機器の進歩発展にはめざましいものが ある。元素分析法では, 原子吸光法分析法に加えて, 誘導 結合プラズマ発光分析法(ICP-AES) と誘導結合プラズマ質 量分析法(ICP-MS)の出現により微量元素分析が一段と容易 になったろ。しかしながら，鉄鋼分析においてこれら分析 法の優れた性能を活かすには，主成分である鉄から目的元 素を前分離することが不可欠である。様々な分離法の中で， 高純度鉄および鋼中の微量不純物元素の定量に適用できる 主な分離法は, 共沈法, 溶媒抽出法, ガス化法, イオン交

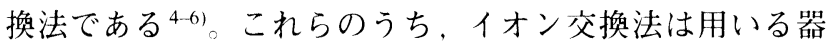
具および操作ともに簡単で，イオン交換体と溶離液の組合 せにより多様な分離系を構成することができ，人体に有毒
な有機溶媒を必要としない特長がある

一般に，原子スペクトル分析法の前分離・濃縮法として のイオン交換分離法は，目的元素を含む溶出液を捕集し才 フラインで測定に供する場合と，溶出液をネブライザーに オンラインで導入する場合とに大別することができる

オフライン分析の例としては, 先ず高純度鉄中 $\mathrm{Mo}, \mathrm{Nb}$, $\mathrm{Sb}, \mathrm{Sn}, \mathrm{Ta}, \mathrm{W}, \mathrm{Zr}$ の ICP-MS 定量の前分離に硝酸-酒石酸 - 過 酸化水素系陽イオン交換》とフッ化水素酸系㓌イオン交 換 ${ }^{7.8}$ の双方が提案されている。また，B選択性イオン交換 樹脂 Amberlite IRA-743を用いて，B局位体希釈ICP-MS により高精度定量した研究もあるり。さらに，高純度鉄中 の $\mathrm{Ag}, \mathrm{Cu}, \mathrm{Mg}, \mathrm{Pb}, \mathrm{Zn}$ はフッ化水素酸系陽イオン交換によ り分離し，同位体希橎ICP-MSにより定量できる10)。なお， 同じフッ化水素酸系陰イオン交換ではあるが，カラムに溶 離液を循環させると高純度鉄中の $\mathrm{B}, \mathrm{Mo}, \mathrm{Nb}, \mathrm{Sn}, \mathrm{Ta}, \mathrm{W}, \mathrm{Zr}$ をICP-AESで高感度同時定量ができる11。

オンライン分離濃縮の例としては, Amberlite IRA-743 ${ }^{(2)}$ あるいは陽イオン交換樹脂(3)を充填したカラムを分析シス テムに組込み，ICP-AESによるB 定量の感度と所要時間を 改善した報告がある。また、陰イオン交換樹脂カラムを導

平成 10年6月30日受付平成 10 年. 8 月 31 日受理 (Received on June 30, 1998; Accepted on Aug. 31, 1998)

* 千葉大学. I: 学部 (Faculty of Engineering, Chiba University, 1-33 Yayoi-cho Inage-ku Chiba 263-8522)

*2 日産化学 [.業（株） 中央研究所 (Central Research Institute, Nissan Chemical Industries, Ltd.)

*3 新日本製鐵（株）先端技術研究所（現（社）日本分析化学会）(Advanced Technology Research Lab., Nippon Steel Corp., now The Japan Society for Analytical Chemistry)

*4 鋼管計測 (株) 分析センター (Analytical Center, Kohkankeisoku Corp.) 
Table 1. Operating conditions of the ICP-AES instrument.

\begin{tabular}{lc}
\hline Frequency $/ \mathrm{MHz}$ & 27.12 \\
$\mathrm{RF}$ power $/ \mathrm{kW}$ & 1.2 \\
Flow rate of Ar/l/min & 14 \\
Plasma gas & 1.5 \\
Auxiliary gas & 1.0 \\
Carrier gas & 15 \\
Observation height in plasma/mm & Wavelength $/ \mathrm{nm}$ \\
Integration time & Mo 202.00 \\
Mo $25 \mathrm{~s} \times 5$ times & $\mathrm{Fe} 259.94$ \\
Fe $25 \mathrm{~s} \times 3$ times & $\mathrm{Al} 396.15$ \\
Al $25 \mathrm{~s} \times 3$ times & $\mathrm{Mn} 257.61$ \\
Mn $25 \mathrm{~s} \times 3$ times & $\mathrm{Co} \mathrm{228.62}$ \\
Co $25 \mathrm{~s} \times 3$ times & $\mathrm{Ni} 231.60$ \\
Ni $25 \mathrm{~s} \times 3$ times & $\mathrm{Y} 371.06$ \\
$\mathrm{Y} 25 \mathrm{~s} \times 3$ times & \\
\hline
\end{tabular}

入したフローインジェクションシステムにより， $\mathrm{Nb}(\mathrm{V})$, $\mathrm{Ta}(\mathrm{V}), \mathrm{W}(\mathrm{VI}), \mathrm{Zr}(\mathrm{IV})$ を ICP-MSにて定量する方法も提案さ れている ${ }^{14)}$

本研究では, 取扱いの面倒なフッ化水素酸を用いること なく，このたび新規に開発した硫酸系陰イオン交換または 既報の塩酸-シュウ酸-過酸化水素系陽イオン交換 ${ }^{15)} に よ$ つて Fe(III)を除去し，目的成分をICP-AESまたはフレーム 原子吸光分析法(FAAS)により定量することを試みた。そ の結果, 前者では鉄鋼中の Mo, 後者では $\mathrm{Al}, \mathrm{Mn}, \mathrm{Ni}, \mathrm{Co} に$ ついて, 適切な精度で保証值とよく一致する分析值が得ら れたので報告する。

\section{2. 実験方法}

\section{$2 \cdot 1$ 試薬}

鉄標準溶液 $(10 \mathrm{mg} / \mathrm{ml})$ は, $\mathrm{FeCl}_{3} \cdot 6 \mathrm{H}_{2} \mathrm{O}$ の $24.2 \mathrm{~g}$ を $0.1 \mathrm{M}$ 塩 酸 $500 \mathrm{ml}$ に溶解して調製し, バリアミンブルーBを指示薬 として $0.01 \mathrm{M}$ EDTAで標定した。モリブデン標準溶液 $(1 \mathrm{mg} / \mathrm{ml})$ は, $\left(\mathrm{NH}_{4}\right)_{6} \mathrm{Mo}_{7} \mathrm{O}_{24} \cdot 4 \mathrm{H}_{2} \mathrm{O}$ の $0.184 \mathrm{~g}$ を $0.5 \mathrm{M}$ アンモ ニアに溶解し， $100 \mathrm{ml}$ とした。その他の金属標準溶液は， 関東化学製原子吸光分析用標準液（いずれも $1000 \mathrm{ppm}$ ) を用いた。塩酸，硝酸および硫酸は関東化学製原子吸光分 析用, その他の試薬は特級品, 水は蒝留・脱イオン水を使 用した。

陰イオン交換分離には，TEVA樹脂（粒径 $100 \sim 150 \mu \mathrm{m}$, EIChroM Industries, Inc., Darien, IL, USA）を用いた。本樹 脂は，疎水性樹脂にジデシルメチルオクチルアンモニウム 塩を担持させたものである。この樹脂によるカラム分離に は， $5 \mathrm{~g}$ の TEVA 樹脂を内径 $14 \mathrm{~mm}$ のガラスカラムに詰め, ベット高さ $115 \mathrm{~mm}$ としたものを使用した。

陽イオン交換分離には強酸性陽イオン交換樹脂Bio-Rad AG50W-X8，100-200 メッシュ，Cl形(Bio-Rad Labaratories, Hercules, CA, USA)を採用した。陽イオン交換カラムは, $5 \mathrm{~g}$ の Bio-Rad AG50Wを内径 $10 \mathrm{~mm}$ の゙ラスカラムに詰 め,ベッド高さ $115 \mathrm{~mm}$ としたものを用いた。
Table 2. Operating conditions of the AAS instrument.

\begin{tabular}{cc}
\hline Flow rate/l/min & \\
Acetylene gas & 2.5 \\
Auxiliary gas & 10 \\
Wavelength/nm & \\
$\mathrm{Mg}$ & 285.2 \\
$\mathrm{Mn}$ & 279.5 \\
$\mathrm{Fe}$ & 248.3 \\
$\mathrm{Co}$ & 240.7 \\
$\mathrm{Ni}$ & 232.0 \\
\hline
\end{tabular}

\section{$2 \cdot 2$ 装置}

ICP-AESには多元素同時分析用島津ICPV-1000型装置を Table 1 に示す条件で使用した。また, FAASには島津AA630-12型装置に $100 \mathrm{~mm}$ のバーナーヘッド（アセチレン空気フレーム）を取付け Table 2 に示す条件で用いた。な お，“1滴法”FAASでは，上記装置に日立 561 型記録計を 接続し, Uchida $5^{16)}$ が設計製作したテフロンロートを噴霧 器のニードルに直接取付け, これにマイクロピペット(Oxford 7000, Oxford Laboratories, Foster City, CA, USA)で試料 溶液 $100 \mu \mathrm{l}$ を注入した。

\section{$2 \cdot 3$ 操作}

$2 \cdot 3 \cdot 1$ TEVA樹脂に対する金属イオンの分配係数 $\left(K_{\mathrm{d}}\right)$ の 測定

約 $100 \mu \mathrm{g}$ の金属イオンを含む $40 \mathrm{ml}$ の鉱酸溶液に $0.1 \mathrm{~g}$ の TEVA 樹脂を加え, $25^{\circ} \mathrm{C}$ で 2 時間振盪した。樹脂をろ別し， ろ液中の金属イオンをFAASまたはICP-AESにより定量し て，次式により $K_{\mathrm{d}}$ を算出した。

$K_{\mathrm{d}}=$ 樹脂 $1 \mathrm{~g}$ 中の金属イオン量 $(\mu \mathrm{g}) /$ 溶液 $1 \mathrm{ml}$ 中の金 属イオン量 $(\mu \mathrm{g})$

$2 \cdot 3 \cdot 2$ 陰イオン交換分離を利用した鉄鋼中Moの定量

$50 \mathrm{mg}$ の試料をはかり取り， $2 \mathrm{ml}$ の $6 \mathrm{M}$ 塩酸と 1 滴の $30 \%$ 過酸化水素水を加えて加熱分解した。蒸発濃縮後 $2 \mathrm{ml}$ の $5 \mathrm{M}$ 硫酸を加え，わずかに白煙が発生するまで加熱した。 冷却してから水を加え, 不溶物が生じた場合(JSS 503-6)に はろ別し, 全容を $50 \mathrm{ml}$ に希釈した。この溶液から $5 \mathrm{ml}$ 分取し，水で全容を約 $20 \mathrm{ml}$ に希釈ののちコンデショニン グ済みの TEVA 樹脂カラムに毎分 $0.5 \mathrm{ml}$ の流量で流した。 $20 \mathrm{ml} 0.05 \mathrm{M}$ 硫酸でカラムを洗浄後 $20 \mathrm{ml}$ の $7 \mathrm{M}$ 硝酸で Mo を溶離し，溶出液をそのまま用いて ICP-AESで定量した。

$2 \cdot 3 \cdot 3$ 陽イオン交換分離を利用した鉄鋼中 $\mathrm{Al}, \mathrm{Mn}, \mathrm{Ni}$, Coの定量

鉄鋼試料 $50 \mathrm{mg}$ をはかり取り, $2 \cdot 3 \cdot 2$ と同様にして溶解 し，ほぼ蒸発乾固した。残留物を $0.5 \mathrm{M}$ 塩酸一 $0.05 \mathrm{M}$ シュ ウ酸 $-1.2 \%$ 過酸化水素溶液に溶解して全容を $100 \mathrm{ml}$ とし， あらかじめコンデショニングしておいた陽イオン交換カラ ムに毎分 $1 \mathrm{ml}$ の流量で流した。䋨いて $40 \mathrm{ml}$ の $0.5 \mathrm{M}$ 塩 酸- $0.05 \mathrm{M}$ シュウ酸- $1.2 \%$ 過酸化水素溶液打よび $30 \mathrm{ml}$ の水 で順次力ラムを洗浄した後， $30 \mathrm{ml}$ の $4 \mathrm{M}$ 塩酸により目的 
Table 3. Distribution coefficients $\left(K_{\mathrm{d}}\right)$ on TEVA resin in nitric acid media.

\begin{tabular}{ccccccc}
\hline \multirow{2}{*}{ Metal } & \multicolumn{7}{c}{$\mathrm{HNO}_{3} / \mathrm{M}$} & & \\
& 0.1 & 0.3 & 0.5 & 1.0 & 3.0 & 5.0 \\
\hline $\mathrm{Fe}(\mathrm{III})$ & 25 & 15 & 6 & 0 & 0 & 0 \\
& $(0)$ & & $(0)$ & $(0)$ & & \\
$\mathrm{Mo}(\mathrm{VI})$ & 178 & 115 & 234 & 141 & 143 & 124 \\
& $(30)$ & & $(6)$ & $(3)$ & & \\
\hline
\end{tabular}

Values in parentheses are $K_{\mathrm{d}}$ on Dowex 1-X10 by a batch method ${ }^{221}$.

Table 4. Distribution coefficients $\left(K_{d}\right)$ on TEVA resin in sulfuric acid media.

\begin{tabular}{|c|c|c|c|c|c|c|c|}
\hline \multirow{2}{*}{ Metal } & \multicolumn{7}{|c|}{$\mathrm{H}_{2} \mathrm{SO}_{4} / \mathrm{M}$} \\
\hline & 0.05 & 0.1 & 0.3 & 0.5 & 1.0 & 3.0 & 5.0 \\
\hline $\mathrm{Fe}(\mathrm{III})$ & 0 & $\begin{array}{l}0 \\
(9.1)\end{array}$ & 0 & 0 & $\begin{array}{c}0 \\
(0.9)\end{array}$ & 0 & 22 \\
\hline $\mathrm{Mo}(\mathrm{VI})$ & $\begin{array}{l}5150 \\
(527)^{\text {a) }}\end{array}$ & $\begin{array}{c}356 \\
(671)\end{array}$ & 126 & 66 & $\begin{array}{c}72 \\
(232)\end{array}$ & 57 & 86 \\
\hline
\end{tabular}

Values in parentheses are $K_{\mathrm{d}}$ on Bio-Rad AG1-X8 by a batch method ${ }^{23)}$. ${ }^{a}$ Value obtained in $0.06 \mathrm{M}$ sulfuric acid

金属を一括してカラムから溶離した。溶出液を蒸発乾固し，

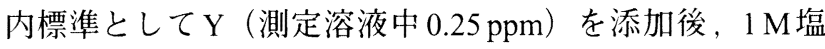
酸で $20 \mathrm{ml}$ としてから ICP-AESにて同時定量した。また FAAS でCo と Mn を高感度で測定する場合は, 溶出液を蒸 発乾固した後 $2 \mathrm{ml}$ の $1 \mathrm{M}$ 塩酸溶液とし, その $100 \mu \mathrm{l} マ$ をイ クロピペットでテフロンロートに注入する“1滴法”によ り測定した。

\section{3. 結果と考察}

\section{$3 \cdot 1$ 陰イオン交換系の利用}

$3 \cdot 1 \cdot 1$ 鉱酸溶液系における TEVA樹脂への金属イオンの 吸着挙動

TEVA樹脂は，硝酸溶液系で Tc(VII), Pu(IV), Np(IV), Th(IV)に対し，塩酸溶液系では Tc(VII), Pu(IV), Np(IV),

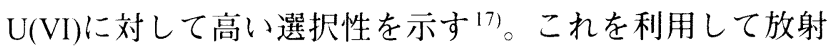
性廃液中のアクチノイドの濃縮 ${ }^{17)}$, 水試料 ${ }^{18)}$, 土壤試料 ${ }^{19)}$ および放射性廃棄物中 ${ }^{201} の{ }^{99} \mathrm{Tc}$ の測定に利用されている. しかし，その他の金属イオンの本樹脂に対する吸着性に関 しては明らかでない。よって，本研究では先ずFe(III)と $\mathrm{Mo}(\mathrm{VI}) に つ い て ， 0.1 \sim 5 \mathrm{M}$ の硝酸系および $0.05 \sim 5 \mathrm{M}$ 硫酸 系の $K_{\mathrm{d}}$ 值を測定した。結果を Table 3 および4に示す。両 系の $K_{\mathrm{d}}$ 值は，通常の強塩基性陰イオン交換樹脂（Bio- $\mathrm{Rad}$ AG1 はDowex 1 を精製したもの）の硝酸系 ${ }^{21}$ および硫酸 系 ${ }^{22) に お け る ~} K_{\mathrm{d}}$ 值（一部を Table 3 と4に示す）に傾向が 類似しているが，值の大きさに若干差が認められる。 $\mathrm{Fe}(\mathrm{III})$ は希硝酸及び希硫酸中でほとんど錯生成しないた め, TEVA 樹脂, Dowex 1 (Bio-Rad AG1)ともにごく弱く吸 着される，あるいは吸着されない。一方，Mo(VI)は硝酸 溶液では酸濃度にほとんど無関係にTEVA樹脂に対し

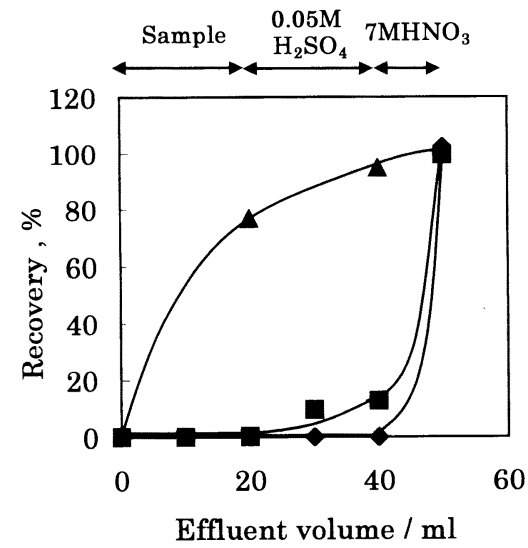

Fig. 1. Elution behavior of Mo(VI). Sample: $20 \mathrm{ml}$ of $0.05 \mathrm{M}$ sulfuric acid solution containing $\mathrm{Mo}(\mathrm{VI})$ $100 \mu \mathrm{g}+\mathrm{Fe}(\mathrm{III})[50 \mathrm{mg}(\boldsymbol{\Delta}) ; 5 \mathrm{mg}(\boldsymbol{\square}) ; 1 \mathrm{mg}(\bullet)]$. Column: $1 \mathrm{~g}$ TEVA resin $(10 \mathrm{~mm}$ i.d. $\times 38 \mathrm{~mm})$.

$100 \sim 200$ 前後の $K_{\mathrm{d}}$ 值を示し，同濃度硝酸について比較す るとDowex 1の場合の6〜50倍に相当する。硫酸系では， $\mathrm{Mo}(\mathrm{VI})$ は薄い酸濃度領域でTEVA 樹脂に非常に強く吸着さ れ，酸濃度の増加とともに急激に減少する傾向が見られる。 共通する硫酸濃度について両イオン交換体に対する $K_{\mathrm{d}}$ 值 を比較すると, Bio-Rad AG1の方が TEVA樹脂より2 3 倍 大きくなっている。

以上の結果から，TEVA 樹脂を希硫酸系で用いれば， $\mathrm{Fe}(\mathrm{III})$ から Mo(VI)を分離濃縮できると考えられる。

\section{$3 \cdot 1 \cdot 2$ 鉄鋼中の Moの定量}

予備実験として，100 $\mu \mathrm{g}$ の $\mathrm{Mo}(\mathrm{VI})$ に異なる量の Fe(III)を 共存させ, $20 \mathrm{ml}$ の $0.05 \mathrm{M}$ 硫酸溶液から $1 \mathrm{~g}$ の TEVA 樹脂力 ラム（内径 $1 \mathrm{~mm}$, ベット高さ $38 \mathrm{~mm}$ ）に $\mathrm{Mo}(\mathrm{VI})$ を吸着させ ることを試みた。その結果，Fig. 1に示すように，Mo(VI) は $50 \mathrm{mg}$ の Fe(III)が共存すると， $K_{\mathrm{d}}$ 值から予想されるより も遙かに早く $0.05 \mathrm{M}$ 硫酸によるカラム洗浄の初期から溶出 した。Fe(III)の量を $1 \mathrm{mg}$ まで減らすと，Mo(VI)は $20 \mathrm{ml}$ の $0.05 \mathrm{M}$ 硫酸でカラムを洗浄しても溶出しないことがわかっ た。よって, 実際の分析操作を想定してTEVA樹脂量を $5 \mathrm{~g}$ に増し， $5 \mathrm{mg}$ の $\mathrm{Fe}(\mathrm{III})$ から $100 \mu \mathrm{g}$ の $\mathrm{Mo}(\mathrm{VI})$ の分離を試 みた。その結果, Fig. 2に示すように Fe(III)がカラムから 完全に溶出するまでMo(VI)はカラム内に留まり，その後 $7 \mathrm{M}$ 硝酸によって定量的に溶離できることが確認できた。

なお，希硫酸溶液から $\mathrm{Mo}(\mathrm{VI})$ を Bio-Rad AG1 に吸着させ ようとすると，大きな $K_{\mathrm{d}}$ 值に反して一部が吸着されずに 漏洩する22)。これを防止するには過酸化水素の添加が不可 欠である。一方，TEVA樹脂では，上述のように，過酸化 水素を含まない希硫酸溶液から $\mathrm{Mo}(\mathrm{VI})$ を定量的に吸着さ せることができ，操作が容易であった。

以上の検討結果を踏まえ, $2 \cdot 3 \cdot 2$ に示す分析操作によ り日本鉄鋼認証標準物質 2 種類を対象としてMo を定量し たところ Table 5に示す結果が得られた。各分析值は保証 值とよく一致しており，再現性も満足できるものである。 


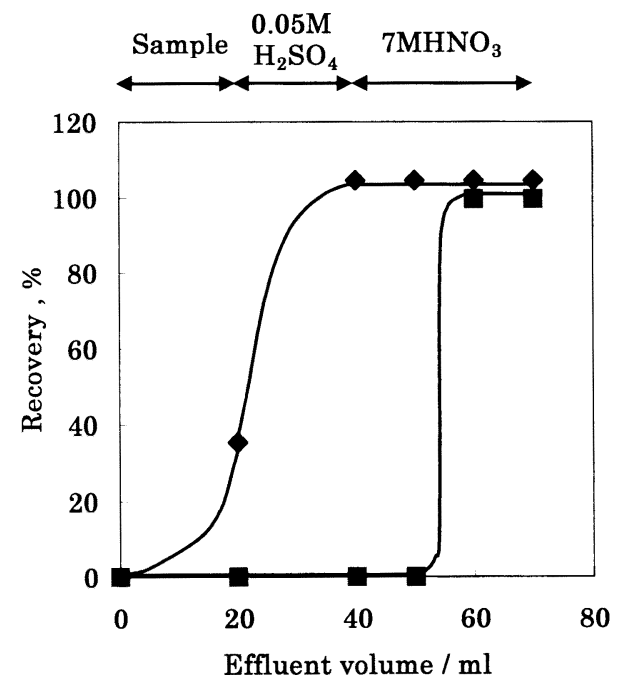

Fig. 2. Elution behavior of $\mathrm{Fe}(\mathrm{III})(\diamond)$ and $\mathrm{Mo}(\mathrm{VI})$ Sample: $20 \mathrm{ml}$ of $0.05 \mathrm{M}$ sulfuric acid solution containing Mo(VI) $100 \mu \mathrm{g}+\mathrm{Fe}(\mathrm{III}) 5 \mathrm{mg}$. Column: $5 \mathrm{~g}$ TEVA resin $(14 \mathrm{~mm}$ i.d. $\times 115 \mathrm{~mm})$.

Table 5. Determination of Mo in steel certified reference materials $(\mathrm{m} / \mathrm{m} \%, \mathrm{n}=4)$

\begin{tabular}{lcc}
\hline \multicolumn{1}{c}{ Sample } & \multicolumn{1}{c}{ Found } & Certified \\
\hline $\begin{array}{l}\text { JSS 503-6 } \\
\text { (Nickel Chromium Steel SNC236) }\end{array}$ & $0.0123 \pm 0.0010$ & 0.013 \\
$\begin{array}{l}\text { JSS 650-10 } \\
\text { (Stainless Steel SUS 430) }\end{array}$ & $0.0199 \pm 0.0003$ & 0.021 \\
\hline
\end{tabular}

\section{$3 \cdot 2$ 陽イオン交換系の利用}

\section{$3 \cdot 2 \cdot 1$ シュウ酸-塩酸-過酸化水素系における金属イオ ンの陽イオン交換挙動}

金属イオンは希塩酸溶液から強酸性陽イオン交換樹脂に 吸着される。その際，正電荷の大きい金属イオンほど強く 吸着される傾向がある。しかし，ここにシュウ酸を加える と多価金属イオンの多くはオキサラト錯体となり，強酸性 陽イオン交換樹脂に吸着されにくくなる。Kurodaら ${ }^{(5)} に$ 上れば, $0.5 \mathrm{M}$ 塩酸- $0.05 \mathrm{M}$ シュウ酸 $-1.5 \%$ 過酸化水素溶液 において過酸化水素がシュウ酸による Fe(III)の還元を防止 し，Fe(III)はオキサラト錯体として保たれる。そのため，

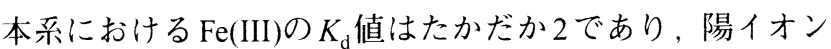
交換樹脂力ラムに吸着されずに溶出する。他方， $\mathrm{Al}(\mathrm{III})$, $\mathrm{Mn}(\mathrm{II}), \mathrm{Ni}(\mathrm{II}), \mathrm{Co}(\mathrm{II}), \mathrm{Zn}(\mathrm{II})$ は本系において 100 前後の $K_{\mathrm{d}}$ 値 を示し，陽イオン交換樹脂カラムに吸着される。また，こ れらの金属イオンは，4M塩酸系で陽イオン交換樹脂に対 し2 3の $K_{\mathrm{d}}$ 值を示すため ${ }^{23)}$ ，4M塩酸により陽イオン交換 樹脂から容易に溶離回収できるものと推測される。従って， 塩酸-シュウ酸-過酸化水素系陽イオン交換は，鉄鋼試料 のマトリックスである鉄を除き， $\mathrm{Al}, \mathrm{Mn}, \mathrm{Ni}, \mathrm{Co}, \mathrm{Zn}$ などを 陽イオン交換樹脂力ラムに捕集するのに適していると考え られる。

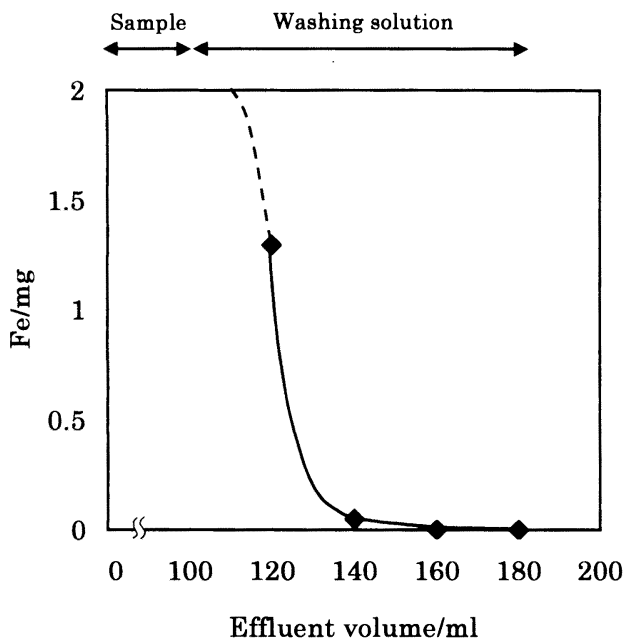

Fig. 3. Elution behavior of Fe(III). Sample: $100 \mathrm{ml}$ of $0.5 \mathrm{M}$ hydrochloric acid- $0.05 \mathrm{M}$ oxalic acid- $-1.5 \%$ hydrogen peroxide containing $10 \mathrm{mg} \mathrm{Fe}(\mathrm{III})$. Washing solution: $0.5 \mathrm{M}$ hydrochloric acid- $0.05 \mathrm{M}$ oxalic acid- $1.5 \%$ hydrogen peroxide. Column: $5 \mathrm{~g}$ BioRad AG 50W-X8 (10 mm i.d. $\times 95 \mathrm{~mm})$.

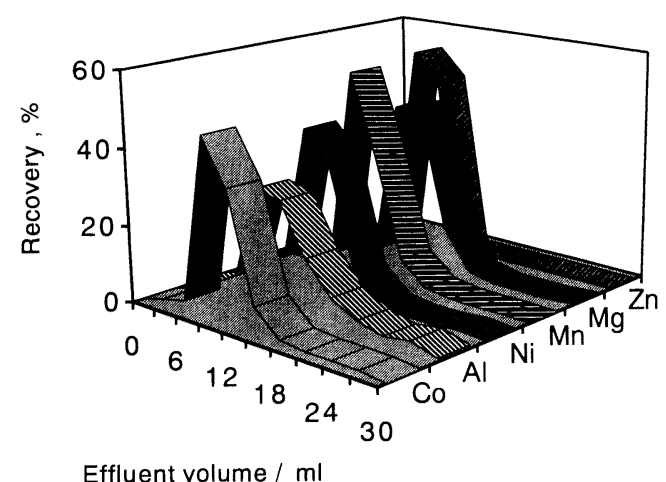

Fig. 4. Elution behavior of $\mathrm{Mg}(\mathrm{II}), \mathrm{Al}(\mathrm{III}), \mathrm{Mn}(\mathrm{II}), \mathrm{Ni}(\mathrm{II})$ and $\mathrm{Co}(\mathrm{II})$. Sample: $100 \mathrm{ml}$ of $0.5 \mathrm{M}$ hydrochloric acid $-0.05 \mathrm{M}$ oxalic acid- $1.5 \%$ hydrogen peroxide containing metal ions $100 \mu \mathrm{g}$ each. Eluent: $4 \mathrm{M}$ hydrochloric acid. For washing solution and column, see Fig. 3.

\section{$3 \cdot 2 \cdot 2$ 鋼中 $\mathrm{Al}, \mathrm{Mn}, \mathrm{Ni}, \mathrm{Co}$ の定量}

実試料の分析の前に, 先ず $\mathrm{Fe}(\mathrm{III})$ の溶離挙動を調べた。 $10 \mathrm{mg}$ の $\mathrm{Fe}(\mathrm{III})$ を含む $100 \mathrm{ml}$ の $0.5 \mathrm{M}$ 塩酸- $0.05 \mathrm{M}$ シュウ酸$1.5 \%$ 過酸化水素溶液として陽イオン交換樹脂カラムに通 し, 引き続いて $0.5 \mathrm{M}$ 塩酸 $-0.05 \mathrm{M}$ シュウ酸 $-1.5 \%$ 過酸化水 素溶液でカラムを洗浄した。カラムからの溶出液を $20 \mathrm{ml}$ ずつ捕集して $\mathrm{Fe}(\mathrm{III})$ の含有量を調べた結果を Fig. 3 に示す。 $\mathrm{Fe}(\mathrm{III})$ はとんどカラムを素通りし, 試料溶液を流した後 に $40 \mathrm{ml}$ の洗浄液を流すとカラムから完全に溶出すること がわかった。

次に, $\mathrm{Al}(\mathrm{III}), \mathrm{Mg}(\mathrm{II}), \mathrm{Mn}(\mathrm{II}), \mathrm{Ni}(\mathrm{II}), \mathrm{Co}(\mathrm{II}), \mathrm{Zn}(\mathrm{II})$ 各 $100 \mu \mathrm{g}$ を含む $100 \mathrm{ml}$ の $0.5 \mathrm{M}$ 塩酸 $-0.05 \mathrm{M}$ シュウ酸 $-1.5 \%$ 過酸化水 素溶液を陽イオン交換樹脂カラムに通し， $40 \mathrm{ml}$ の $0.5 \mathrm{M}$ 塩 酸 $-0.05 \mathrm{M}$ シュウ酸 $-1.5 \%$ 過酸化水素溶液および $30 \mathrm{ml}$ の水 でカラムを洗浄した。その後，カラムに吸着した金属を 
Table 6. Determination of $\mathrm{Al}, \mathrm{Mn}, \mathrm{Ni}$ and $\mathrm{Co}$ in iron and steel certified reference materials $(\mathrm{m} / \mathrm{m} \%, \mathrm{n}=4)$.

\begin{tabular}{|c|c|c|c|c|}
\hline Sample & $\mathrm{Al}$ & $\mathrm{Mn}$ & $\mathrm{Ni}$ & $\mathrm{Co}$ \\
\hline JSS $650-10^{\mathrm{a}) *}$ & & $\begin{array}{l}0.45 \pm 0.001 \\
(0.44)\end{array}$ & $\begin{array}{c}0.40 \pm 0.003 \\
(0.39)\end{array}$ & $\begin{array}{c}0.022 \pm 0.0001 \\
(0.024)\end{array}$ \\
\hline JSS $174-5^{\mathrm{b}) *}$ & $\begin{array}{c}0.046 \pm 0.0024 \\
(0.038)\end{array}$ & $\begin{array}{l}0.41 \pm 0.001 \\
(0.40)\end{array}$ & & $\begin{array}{c}0.020 \pm 0.001 \\
(0.021)\end{array}$ \\
\hline JSS $003-4^{\mathrm{c}) * *}$ & & $\begin{array}{c}0.0035 \pm 0.0001 \\
(0.0038)\end{array}$ & & $\begin{array}{c}0.0029 \pm 0.00002 \\
(0.0029)\end{array}$ \\
\hline $\begin{array}{l}\text { BCS/SS-CRM } \\
\text { No. } 486 / 1^{\mathrm{d} / *}\end{array}$ & $0.014 \pm 0.001$ & $\begin{array}{l}0.20 \pm 0.006 \\
(0.21)\end{array}$ & $0.083 \pm 0.002$ & $\begin{array}{c}0.080 \pm 0.002 \\
(0.08)\end{array}$ \\
\hline
\end{tabular}

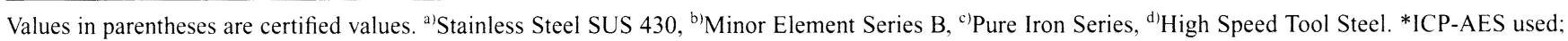
**، one-drop' FAAS used.

$4 \mathrm{M}$ 塩酸で溶離し，溶出液を $3 \mathrm{ml}$ ずつ分取して金属を測定 した。その結果を Fig. 4 に示す。Al(III)は溶離が若干緩や かであるが， $30 \mathrm{ml}$ の $4 \mathrm{M}$ 塩酸で回収されている。一方， 2 価金属イオンは $20 \mathrm{ml}$ 以下の $4 \mathrm{M}$ 塩酸で定量的に溶離され ている。

以上の結果を踏まえ，2·3·3に示す操作により日本鉄 鋼認証標準物質 3 種類およびBritish Chemical Standard and Euronorm Certified Reference Materials 1 種類を分析した。そ の結果を Table 6に示す。得られた值はいずれも保証值と よく一致し，再現性も良好である。なお，JSS 174-5の Al の定量值が保証值よりも若干大きくなっているのは，実験 環境からの污染によるものと推察される。

\section{4. 結言}

イオン交換法により鉄鋼中の微量金属を前分離し，原子 スペクトル分析法により定量する方法を確立した。

(1) $0.01 \mathrm{~m} / \mathrm{m} \%$ レベルの Moの定量では，希硫酸溶液 とした試料を陰イオン交換樹脂（TEVA 樹脂）カラムに通 し，Moイオンを保持させ，硝酸で溶離して ICP-AESで定 量する。

(2) $0.001 \sim 0.1 \mathrm{~m} / \mathrm{m} \%$ レベルの Al, Mn, Ni, Coの同時定 量では, 塩酸ーシュウ酸一過酸化水素溶液とした試料を陽 イオン交換樹脂(Bio-Rad AG50W)力ラムに通してこれら金 属のイオンを吸着させ，塩酸で溶離して ICP-AESまたは FAASにより定量する。なお， $0.001 \mathrm{~m} / \mathrm{m} \%$ ケベルの定量に は“一滴法”FAASを採用する。

上記の方法により，鉄鋼認証標準物質を分析してほぼ満
足できる結果を得た。

本研究は，(社）日本鉄鋼協会学会部門「有害試薬を用 いない新高感度分析技術研究会」の活動の一環として行わ れたものである。

\section{文献}

1) K.Abiko: Materia Jpn., 33 (1994), 11

2 ) K.Abiko: Met. Technol. Jpn., 65 (1995), 53.

3 ) A. Montaser and D. W. Golightly (ed.): Inductively Coupled Plasmas in Analytical Atomic Spectrometry, 2nd ed., $\mathrm{VCH}$, New York, (1992).

4 ) K.Takada: Materia Jpn., 33 (1994), 84

5 ) K.Takada: Materia Jpn., 33 (1994), 307.

6 ) K.Takada: Bunseki, (1995), 640.

7 ) K.Fujimoto and T.Okano: CAMP-ISIJ, 6 (1993), 1314

8 ) K.Hanada, K.Fujimoto and M. Shimura: CAMP-ISIJ, 10 (1997), 685

9 ) K.Fujimoto, K.Funabashi and T.Okano: CAMP-ISIJ, 7 (1994), 1305.

10) I.Inamoto and K.Chiba: Tetsu-to-Hagané, 79 (1993), 175

11) K.Yamada, O.Kujirai and R.Hasegawa: Anal. Sci., 9 (1993), 385.

12) Y.Takahashi: Bunseki Kagaku, 36 (1987), 693.

13) W.Huanan, C.Yao and W.Jin: Microchem. J., 53 (1996), 88.

14) A.G.Coedo, T.D.Lopez and F.Alguacil: Anal. Chim. Acta, 315 (1995), 331.

15) R.Kuroda and T.Seki: Fresenius' Z. Anal. Chem., 296 (1979), 146.

16) T.Uchida, I.Kojima and C.Iida: Anal. Chim. Acta, 116 (1980), 205.

17) E.P.Horwitz, M.L.Dietz, R.Chiarizia, H.Diamond, S.L.Maxwell, III and M.R.Nelson: Anal. Chim. Acta, 310 (1995), 63.

18) Technetium-99 in Water, Analytical Procedure, TCWO1, EIChroM Industries, Inc., Darien, (1995).

19) Technetium-99 in Soil, Analytical Procedure, TCSO1, EIChroM Industries, Inc., Darien, (1995).

20) O.Egorov, M.J.O'Hara, J.Ruzicka and J.W.Grate: Anal. Chem., 70 (1998), 977.

21) J.P.Faris and R.F.Buchana: Anal. Chem., 36 (1964), 1158.

22) F.W.E.Strelow and C.J.C.Bothma: Anal. Chem., 39 (1967), 595.

23) F.W.E.Strelow: Anal. Chem., 32 (1960), 1185. 